\title{
Local wisdom based disaster education in Minangkabau society
}

\author{
Damsar $^{1, *}$, and Indrayani ${ }^{2}$ \\ ${ }^{1}$ Department of Sociology, University of Andalas, Padang, 25163, Indonesia \\ ${ }^{2}$ Department of Management, University of Batam, Batam, 29432, Indonesia
}

\begin{abstract}
This paper discusses how local wisdom is the basis for disaster education in Minangkabau society. Local wisdom forms the stock of knowledge and practices which is deemed wise and sensible to the various environmental problems, including the issue of disaster. This research aims to find the source of learning of local wisdom and its implementation on disaster management in Minangkabau society. This research was conducted with a qualitative approach, where in-depth interview and observation as data collection tool. In-depth interviewees are 29 people, i.e. 20 people come from ordinary people and 9 people come from leaders (traditional, religious, and community leaders). Observations were conducted on a variety social institutions that contribute to disaster education through various emergency response and recovery activities after the Padang earthquake on September 30, 2009. Data analyses are based on Miles and Huberman models. The results of the research show there are 5 learning resources from Minangkabau local institutions, namely family, "lapau" (traditional coffee house), "surau" (prayer house), "tapian tampek mandi" (the local public bath), and traditional art performances. Through these 5 institutions, the Minangkabau have sources of local wisdom values to face disasters. In case of a disaster, local wisdom is implemented in house construction through the tradition of "gotong-royong" (mutual help), especially in rural areas strengthened by fund-raising based on villages, tribes, and regions by Minang people in overseas.
\end{abstract}

\section{Introduction}

What will happen when the September 30, 2009 earthquake in West Sumatra, if the Minangkabau people have a tradition house roof made of tile? People will agree that more victims will fall due to roof tiles. This is known as local wisdom, which is the way and the community strategy to deal with their physical, ecological, social, cultural and economic environment. Wisdom includes a local scale. It means that the wisdom located in a particular socio-cultural space. So the differences in social and cultural space, despite the physical and ecological environment is relatively the same, may have different local wisdom. For example, Javanese compared to Sundanese, Minangkabau compared to Mandailing, Bugis compared to Makassar, Dayak compared to Banjar, or Aceh compared to Malay. Although the two tribes in a geographical locality are close to each other and have ecological similarities, they may have different local wisdom.

Indeed, in some elements of wisdom, they have the same. Wisdom can be seen through the anticipative and adaptive abilities on various issues of life [1].

Local wisdom is the social perception constructed by members of the community. Local wisdom is built, developed and maintained or enhanced in the process of interaction between the members of the community in the face of various environments [1]. Social wisdom consists of values, knowledge systems, and local technology. Local wisdom, therefore, covers almost all aspects of human life, for examples:

a) Local wisdom in relation to food security: how protected and preserved food sources such as the "fish ban" or "fishpond prohibition". The ban is intended to prevent people to catch fish at a time before the harvest.

b) Local wisdom in relation to the conservation of water resources: how water resources are protected, such as Subak in Bali or waterwheel in Minangkabau.

c) Local wisdom in relation to the utilization of natural resources for the economy: such as the classification of forests according to local law in Minangkabau and Malay, soil classification according to custom.

d) Local wisdom in relation to the settlement: practical guidance on the pattern of traditional houses, the layout of the housing, and so on.

e) Local wisdom in relation to clothing: guidance customary of clothing, woven, and others.

f) Local wisdom in terms of social interaction: guidance customary of social interactions based on gender, age and social status.

g) Social wisdom in conjunction with the anticipation of the future: the customary guidelines on warnings of natural disasters, social conflict, or poverty.

The study of local wisdom has been done by experts [2-5]. The study of local wisdom is an important and interesting thing for the architecture department of the University of Merdeka Malang which has the Journal of

Corresponding author: damsar@soc.unand.ac.id 
the local wisdom. Although many studies on local wisdom have been conducted, special studies on disaster education based on local wisdom are still rarely studied [6]. The study of local wisdom associated with education usually discussing character development based on local wisdom has not been done yet [7]. This study, therefore, is a pilot study on local wisdom-based disaster education. Disaster education was not studied in school like many conducted by several researchers $[6,8-10]$ but at the community level. Disaster education at the community level has been seen through the dissemination of local knowledge in society. Disaster education was not studied in school $[6,8,9]$ but at the community level.

Important questions related to this study are: what is intended by that disaster education based on local wisdom? Is there disaster education based on local wisdom? If there is, what is the disaster education? Furthermore, how disaster education is practiced in Minangkabau society today?

\section{Research methodology}

To answer these questions, a field research was conducted with a qualitative approach, where in-depth interviews and observation were used as data collection techniques. In-depth interviews were conducted on two different groups of people, namely the elite and the common people groups. The elite consist of traditional leaders, religious leaders, and community leaders who had experienced the earthquakes in West Sumatra. It was interviewed as many as 3 of elite groups, in which each elite sub-group was taken, 3 people: traditional, religious and community leaders. Traditional leaders were asked about customary perspectives on disaster. Religious leaders were asked about the religious approach to disaster. While the community leaders were asked about how their involvement in the handling of natural disasters. Whereas the common people group consists of 20 people from various backgrounds and socioeconomic status. In the interview process, the researchers used interview guidelines that contained several important questions to find answers to research questions.

Observations were carried out to local social institutions such as lapau, surau and the local public baths and through involvement in various activities related to emergency response and rehabilitation actions after the Padang earthquake on September 9 in 2009.

Validation of data was done by 2 techniques, namely triangulating the source and performing triangulating techniques. While the data analysis used Miles and Huberman model [10], which consists of data reduction, displaying data, and conclusion drawing/verification.

\section{Result and discussion}

\subsection{Philosophy of "nature unfurled becomes a teacher" as learning sources of local wisdom}

In Minangkabau society, philosophy of "alam takambang jadi guru" (nature unfurled becomes a teacher) is a local wisdom that guides how to think, feel, act and behave in people and/or groups of people in various aspects of life [12]. Source of the value of the adat (custom) that guides the behavior of Minangkabau society is derived from the proverb states "panakiak pisau sirauit, ambiak galah batang lintabuang, salodang ambiak ke niru, nan satitik jadikan lauit, nan sakapa jadikan gunuang, alam takambang jadikan guru" (take the small knife for carving, make a staff from the lintabuang tree, the cover of pinang flowers becomes a window, a drop of water becomes the sea, a clump of earth becomes a mountain, nature unfurled becomes a teacher).

This philosophy has given the Minangkabau a stock of knowledge that provides the order of understanding, guidance, and inspiration in carrying out various aspects of life such as cultural, social, political, economic, and ecological dimensions of life [13, 14]. It has inspired Minangkabau people to produce the proverbs, maxims, quatrains, and couplets associated with various natural phenomena, such as, "bak aia di daun kaladi" ( as water drops on the taro leaf), "bulek aia dek pambuluah, bulek kato dek mufakait" (water is collected in the bamboo pipe, agreement is reached through consensus), "aia beriak tando tak dalam" (moving water runs shallow), or "kabau tagak, kubangan tingga" (buffalo upright, puddles stay).

The cross-interpersonal treatment which is not in accordance with customary guidance about manners, morals, ethics and good morals, may results in horizontal interpersonal conflicts. This wisdom is contained in traditional proverb which says "nak jauh silang sangketo, pahaluih baso jo basi" (if you do not want the dispute, softening your language and manners).

A maxim says "ka bukik samo mandaki, ka lurah samo manurun, tatungkuik samo makan tanah, tatilantang samo minum ambun" (to the hill all climb up, to the cliff all go down, face down all eat dirt, lie on the back all drink drew). This traditional proverb leads people Minangkabau to cooperate in order to achieve the purpose well and harmonization of life can be maintained.

According to the Minangkabau philosophy, justice is a principle that is expected to be upheld by every Minangkabau person. This principle is stated in the proverb follows: "bakati samo barek, maukua samo panjang, tibo di mato indak dipiciangkan, tibo di paruik indak dikampihkan, tibo di dado indak dibusuangkan" (weighing with the same we, measuring with the same length, arriving in the eye is not screwed, arriving in the stomach is not deflated, arriving in the chest is not puffed up).

Minangkabau wisdom provides the guidance of many ways of thinking, feeling, and acting in relation to the economic aspects of life. The Minangkabau wisdom confirms the value of thrift in which the proverb says "bahimek sabalun habih, sadio payuang sabalun hujan. salagi ado disimpan, salagi tido dimakan" (frugality before it runs out, willing umbrella before it rains. When we have to save it when we have nothing eat it). 
In addition, there are various maxims that guide the Minangkabau in the understanding of their ecological environment, such as "gabak di hulu tando ka hujan, cewang di langik tando ka paneh" (cloudy in the upper signs the day will rain, the light in the sky indicates the day will be hot). Such wisdom directs Minangkabau people to pay attention to the signs of nature as a signal of rain or heat.

\subsection{Wisdom based disaster education}

Minangkabau wisdom refers to natural wisdom also contained the wisdom of the disaster. Nature teaches Minangkabau people to understand the behavior, manner, or conduct of its character. The idea of local wisdom contains values that guide, direct, and dictate how the Minangkabau people think, act and behave towards the problems faced [15].

\subsubsection{Ideas of values}

Some ideas of value presented here show that nature is the teacher in an understanding reality of nature itself. Nature gives a lesson in how to be friendly or live with it. Therefore, nature leads people to anticipate the future, including on disasters, in order to avoid the unexpected or to be aware of the symptoms and also teaches how to react to it.

"Jikok takuik dilamun ombak, jan barumah di tapi pantai" (If afraid of waves, do not settle on the waterfront). This proverb, in its essence, is a warning for everyone to beware of waves that will be slammed, hit, or removes everything that is on the edge or near the beach. So this proverb does not forbid people to set up home there.

"Sakali aia gadang, sakali tapian barubah" (Once the flood struck, once the edges changed). This proverb teaches Minangkabau people, that the flood will lead to changes in the edges. It means, the Minangkabau people are taught to be aware of the flood, which always ended in changes to the edges. While the meaning of this proverb is that there are always changes in a man's life when the cause was there.

"Bak aua jo tabiang" (like bamboo with cliffs). Bamboo and cliffs are a relationship of symbiotic mutualism, where the cliff does not collapse together bamboo that thrives in these cliffs. Therefore, the Minangkabau wisdom guides the people to plant bamboo on a cliff along the village. While the meaning is that life is to help each other.

\subsubsection{Practises}

Many praxes of life committed by the Minangkabau shows an anticipatory behavior, actions, deeds, and activities against disasters, namely "rumah gadang" (the big house), the roof of the house, the settlement patterns, and the patterns of agriculture.

The big house is a physical construction of the Minangkabau people's awareness of their nature and environment. It is a physical form of local wisdom to shelter against heat, rain, cold, wild animals, and so on. Construction of the big houses contains values and practices of local wisdom to anticipate earthquakes. The big house built in the shape taper down, like a ship. Each pillar is not upright or horizontal but sloped. The shape taper down makes the big house resistant against the earthquake. Furthermore, all poles of the big house are not implanted into the ground but rely on a flat stone that is strong and wide. All connection of the joints use pins made of woods. When the earthquake occurs, the big house can move flexibly like dancing on a flat stone. Similarly, pins connections also can move flexibly, so the big house is earthquake resistant.

If we trace settlement patterns of traditional Minangkabau society, then almost every the big house provided by rangkiang (rice barn) and tabek (fish pond). There are 3 kinds of rangkiang: (1) The "rangkiang sitinjau lauik", contains rice for the family, particularly for adat ceremonies. (2) The "rangkiang sitangka lapa" conceives rice for donation to poor villagers and for times of famine in the village. (3) The "rangkiang sibayau-bayau" contains rice for the daily needs of the family [16]. Besides for food supplies, tabek is also known as technology may reduce the impact of vibrations from earthquake waves.

In coastal areas, there is a tendency for people to plant coconut trees along the coast. As it is known that palm trees were planted on the beach can be a damper on the enormity of the brunt of the waves, or tsunamis, and withstand the beach from abrasion.

\subsection{The process of disaster education}

The process of disaster education occurs through traditional institutions of socialization such as family, lapau (tavern, traditional coffee house), surau, the local public bath, and performing traditional arts. Lapau is a place to drink and sell basic goods such as chili, cooking oil, instant noodles, and more.

The family is an important institution for socializing the young people. All family members live in the "rumah gadang" (big house). In the big house, a mother resides with her daughters. Inside the big house, there are several rooms that were occupied by her daughter. Whenever a daughter marries, the husband moves into the house of his wife. This means that the big house reflects the Minangkabau extended family. If the big house is not there anymore, so they live in a regular house, which is inhabited by the nuclear family, consisting of mother, father, and children. But usually, a regular house located at or not far from the same location as the big house them first. Under this atmosphere and situation, the young people are educated and socialized by all member of the big house. In other words, their extended family helped care for the young people of Minangkabau. In the big house, the father does not have an important role in educating children. The woman's brother is responsible for her children rather than her husband. Here the women's brother has a prominent role towards children. In contrast to the big house, at the 
regular house, the father has played an important role in the education and development of children. While the role of the women's brother is no longer important. Both forms of the family, their members socialize the value of "adat" (local custom) and Islam to young people, including the idea of value and practices related to adaptation and management of the disaster.

Lapau (traditional coffee house) also serves as a meeting place in the rural community of Minangkabau. Most lapau attended by men, while women came to lapau to buy food or essential goods. In some villages, there are lapau specifically for women. The topic of visitors lapau varied and flowing. All life issues are discussed here, including adaptation and management of the disaster.

Surau is a prayer house and place for basic religious instruction. Religious teachers teach about Islamic values and customs neighbor's life, including entrepreneurship. When surau still serves as sleeping quarters for unmarried adult males, then the footmen who return to hometowns also slept here. Togetherness among young people and migrants in the surau is a process that socialized a wide range of values and life strategy includes adaptation and management of the disaster.

The public bath is a bath for all of the inhabitants in the community. Each village has a public bath, which uses one side of the river, dug wells, or wellsprings. The public bath is not only used for bathing and washing clothes, but also as a source of drinking water for villagers. Because the public bath as a gathering place for the citizens, then it is also used to transmit the values and strategies of action towards all of the life problems, including adaptation and management of the disaster, for its citizens.

Traditional art performances, such as "randai", "saluang", "rabab", and the like, have a significant role in the socialization of traditional values and religion, including the values that contain the entrepreneurial character, to the community. Randai is a folk theatre tradition which combines music, singing, dance, drama and the silat (self-defense arts). Randai is usually presented for traditional festivals and ceremonies, and complex stories may span a number of nights. Randai is a medium to convey the tale or folklore through couplets or poem that contains the values of life, including entrepreneurial characteristics. While saluang is a traditional Minangkabau musical instrument, made of thin bamboo or chamfer (schizostachyum brachycladum Kurz). Saluang accompanied with a song that comes from the poems and the proverbs; so that the values of adat and religion, including adaptation and management of the disaster, could be conveyed to the audience. $R a b a b$ is a Minangkabau traditional stringed instrument, made of coconut shell. As with saluang, rabab is also complemented with the song that the lyrics come from aphorism and the maxims.

Local wisdom, therefore, is local knowledge transmitted through local social institutions such as "lapau", "surau", the public bath, and traditional art performances. The role of these social institutions has become weakened due to the process of modernization and globalization, particularly in an urban area. But local wisdom is in harmony with the wisdom of science, so the idea of values and praxis from local wisdom can be integrated and synergized into formal education, both in national subjects such as natural science as well as localized subject such as Minangkabau Traditional Culture. This is also in line with the proposal to incorporate disaster education into the national curriculum, which is the content of local wisdom on disaster.

\subsection{Implementation of local wisdom in housing construction}

Most people build a house no longer shaped rumah gadang (big house), but an ordinary house like most Indonesian homes. If the Minangkabau build the big house, then they are not entirely referred to the blueprint of the adat. Although the construction of a big house has changed considerably, the basic principle of architecture has not changed, that is, a house with a gonjong (hornlike roof structure) and space and rooms of the big house. Similarly, about material choices, although people can afford to buy ceramic tile, they still refer to local wisdom in choosing materials for the roof, where the choice is zinc or metal tile. The floor and walls are made of bricks. A modern big house is not a house on stilts.

There are several reasons why these things happen, namely: (1). the finest wood and fibers are not commonly found, and when it is very expensive. (2) the master craftsman (tukang tuo) is very few in number. (3) the land is getting narrower, so rangkiang and tabek cannot be made (4) the number of the fields of rice is reduced, so that even if there rangkiang, but rangkiang not contain rice. (5) the choice of roofing material in the form of zinc or metal tile shows the implementation of awareness of local wisdom that has long been crystallized to the fact that Minangkabau people live in disaster-prone areas. Therefore, something above (the roof) should be anticipated so as not to become a disaster carrier in case of an earthquake.

Learning from nature, the Minangkabau have adjusted the ways and techniques in home construction in accordance with the directives of government and experts. As a result, construction costs become more expensive. Because the price of building materials and worker wages become higher. The artisan has the knowledge and technology of how to build the home friendly against earthquakes. They have learned to nature, "nature unfurled becomes a teacher".

\subsection{Implementation of local wisdom in disaster management}

People of West Sumatra have experienced many disasters ranging from floods to earthquakes. Those experiences give them an idea of how local communities and governments deal with the problems of post-disaster. Here is presented a description of how the handling of 
post-earthquake during emergency response, recovery and reconstruction.

\subsubsection{Handling in the emergency response}

Emergency response in the context of local wisdom in the adage referring to the Minangkabau adat, "kaba baiak bahimbauan, kaba buruak bahambauan" (good news alerted, the bad news attended). Its meaning is that if there is good news that people are invited to come to the event, whereas when there is bad news, then people will trickle come without having been invited. Therefore, when disaster 30 September 2009, for example, network Minangkabau migrants across the country collecting funds for disaster victims. Pekanbaru, as one of the cities, that many Minangkabau and became the majority population there, be quiet again deserted, as most of its citizens to return home immediately after the news of the devastating earthquake spread, to help relatives in their hometown respectively.

The residents themselves create a common kitchen to be distributed to residents who were affected by the earthquake in some corners of the city. While residents severely affected housing estates to make a tent for shelter while keeping their property from looting irresponsible people.

It does not mean that the earthquake 30 September 2009 does not have a different picture with the local wisdom "kaba baiak bahimbauan, kaba buruak bahambauan". In fact, after the earthquake, we find a group of people watching the evacuation of casualties, posed with a background of collapsed buildings or personnel are being evacuated. So that it is creating a new phenomenon, namely disaster travelers.

The earthquake on September 30, 2009, in West Sumatra, especially Padang, destroyed public facilities such as hotels, buildings of tutoring, and the building of other education. The quake was crushing, stockpiling, or trapping people in the rubble of the building. So that emergency response requires sophisticated equipment, while the equipment is not available in Padang, if any, is very limited. As a result, the handling was impressed slow and unprofessional. On the other hand, handling the distribution of food, blankets, and other goods at the level of district cities, especially Pariaman City and Padang Pariaman District, is also seen as slow and unprofessional.

\subsubsection{The recovery and reconstruction}

Earthquake 30 September 2009 has invited many donor countries and institutions, both from within and abroad, to help the people of West Sumatra in the construction of shelters in the form of houses. The donor countries and institutions have different systems with one another in the construction of the house. There is three forms of relief: (1) construction of houses until completed and ready to be occupied owner; (2) providing all the building materials are ready to be built. (3) construction of frame home which is friendly against earthquakes.
Except for the construction of houses ready to be used, the pattern of housing construction that involves community participation so that these activities are expected to create self-sufficiency and generate solidarity and cohesion in the society. For many rural areas, particularly in the district of Padang Pariaman, home construction patterns that involve the participation of citizens show success. That is because in the society, especially the Padang Pariaman, has a tradition of gotong-royong (mutual assistance) and tolong menolong (mutual help) through the tradition of badoncek or barantam, that is the tradition of helping (reciprocity) in the community in various aspects of life such ceremonies in the marriage, the construction of houses, death, and so on. Every member of the community donated a sum of money based on their closeness to the parties conducting a ceremonial activity. All donations will be recorded by the perpetrators of the ceremonial activities that point to be returned to those who have contributed when they held a ceremony later. This tradition was experiencing barriers in communities where most people go overseas (merantau) so that staying at home is just old people, women, and children. The logical consequence is the lack of manpower to carry out the tradition. But they have a solution that works that should be done through gotong-royong were hired to the artisan. It can be done because their family is in the overseas providing money and material support for it.

Problems arise in urban areas, where most residents rely on gainful employment wages. Their dependence on wages so that when they do not work, they do not get the money. That means they do not eat. Then the pattern of construction of houses with community participation reaps the problem.

Handling post-earthquake related to psychological and sociological trauma, both during the emergency response and recovery/rehabilitation, almost extremely rare. Because there are storytelling activities and play a group of persons for the children of victims as well as entertainment for the residents at the time of an emergency response. Other than those mentioned just now, psychological and sociological trauma seems to be cured by over time.

\section{Conclusions}

Minangkabau society has local knowledge of nature, whether in the form of ideas and praxis, so they have a guide on how to anticipate disaster. Local knowledgebased disaster education is non-formal education which is constructed by people. Social wisdom is the source of value and a toolkit for the community of Minangkabau in the face of disaster. Value and strategies of action towards disaster are internalized through family, "lapau", "surau", the public bath, and traditional art performances.

\section{References}

1. Damsar, (Introduction to rural sociology) (Prenadamedia Group, Jakarta, 2016) 
2. Sukmawati, Development of supplementary materials for teaching local knowledge based on local wisdom about the preservation of Ammatoa customary forests in Bulukumba Regency, South Sulawesi, (Magister thesis. unpublished, State University of Malang, 2015)

3. Wagiran, Character development based on local wisdom of Hamemayu hayuning bawana: identification of values based on cultural character, Jur. Pend. Karak. 2, 3 (2012)

4. A. Musanna, Rationality and actuality of local wisdom as the basis for character education, Jur. Pend. \& Keb. 17, 6 (2011)

5. K, Kongprasetamorn, Local wisdom, environmental protection and community development: the clam farmers in Tambon Bangkhunsai, Phetchaburi Province, Thailand. Man. J. Hum. 10, 1 (2007)

6. M. Desfandi, Urgency of disaster education curriculum based on local wisdom in Indonesia, Sos. Didak.. 1, 2 (2014)

7. Y. Ruyadi, Character education model based on local cultural wisdom: research on indigenous people of Kampung Benda Kerep Cirebon, West Java Province for the development of character education in schools) in Proceedings of The 4th International Conference on Teacher Education; Join Conference UPI \& UPSI Bandung, Indonesia, (2010).

8. L. Honesti, N. Djali, Disaster education in schools in Indonesia is based on several perspectives of the discipline of science, J. Moment, J. Moment. 12,1 (2012)

9. S. I. Astuti, Sudaryono, The role of schools in learning disaster mitigation. J.D.P.B. 1,1 (2010)

10. M. B. Miles, A. M. Huberman, Qualitative data analysis (Sage Publications, Thousand Oaks, CA. 1994)

11. Karyono, Disaster mitigation education in social science education in Indonesia, in Proceedings National Seminar of Education in Social Sciences. Sekolah Pascasarjana Universitas Pendidikan Indonesia (2010)

12. M. Nasroen, Basic Minangkabau customary philosophy (Bulan Bintang, Jakarta, 1971)

13. Damsar, Minangkabau Culture: nature as a teacher, in the UGM PUSPAR Team, eds. Cultural insight for development: looking at local wisdom (Pilar Politika, Yogyakarta, 2004)

14. Damsar, Ulayat land and the socio-cultural economic resilience of the Minangkabau people in Kasryno, ed. Customary land and Minangkabau rice culture (Yayasan Padi Indonesia, Jakarta, 2005)

15. Damsar, Z. Arifin. In the context of local wisdom and nationalism: cases of natural disasters 30/S/2009" in Y. Narny, F.H. Sufyan, eds. Proceedings Nationalism in Indonesia and Other
Southeast Asian Countries, (BPSNT Padang Press, Padang, 2011)

16. A. A. Navis, Alam takambang is a teacher: Minangkabau customs and culture (Grafitipers, Jakarta, 1984) 